\title{
PEMETAAN TATA GUNA LAHAN PERTANIAN DAN PERKEBUNAN DI KABUPATEN EMPAT LAWANG
}

\author{
Eka Puji Agustini ${ }^{1}$, A.Zahrun Suyudi ${ }^{2}$, \\ Universitas Bina Darma \\ Jalan Jenderal Ahmad Yani No.3 Palembang \\ Sur-el : eka_puji@binadarma.ac.id1, zahrunsuyudi8@gmail.com²
}

\begin{abstract}
Land use is very important for local governments to know the potential income that exists. Utilization of GIS in analyzing and representing natural conditions with the help of spatial and non-spatial data in Empat Lawang Regency. The purpose of this study was to map using the scoring and overlay methods by looking at the map data of soil type, rainfall, land use, and slope. The final result of the overlay distribution of agricultural and plantation land was analyzed that the distribution of plantation land overlays dominated with coffee plantation types in Ulu Musi District, Pendopo, West Pendopo, Right Lintang, Muara Pinang, Turbid Air Pasemah, and Attitude In the data seen from 4 maps parameters and adjust the final result data. Meanwhile, agricultural land is smaller and dominated by rice in the Pendopo, Lintang Kanan, Pasemah Air Keruh, Ulu Musi, Talang Padang and Tebing Tinggi sub-districts. While the overlay distribution with data on 3 parameters of plantation and agricultural land use is included in the category of ordinary production forest which can be categorized as safe forest use.
\end{abstract}

Keywords : Land Use, GIS, Scoring, Overlay.

Abstrak: Tata guna lahan menjadi sangat penting bagi Pemerintah daerah untuk mengetahui potensi-potensi penghasilan yang ada. Pemanfaatan SIG dalam menganalisa dan merepresentasikan kembali kondisi alam dengan bantuan data spasial dan nonspasial di Kabupaten Empat Lawang. Tujuan penelitian ini untuk melakukan pemetaan menggunakan metode scoring dan overlay dengan melihat data peta jenis tanah, curah hujan, penggunaan lahan, dan kemiringan lereng. Hasil akhir dari sebaran overlay dari lahan pertanian dan perkebunan dianalisis bahwa sebaran overlay lahan perkebunan lebih mendominasi dengan jenis perkebunan Kopi di Kecamatan Ulu Musi, Pendopo, Pendopo Barat, Lintang Kanan, Muara Pinang, Pasemah Air Keruh, dan Sikap Dalam data dilihat dari 4 peta parameter dan menyesuaikan data hasil akhir. Sedangkan untuk lahan pertanian lebih kecil dan didominasi oleh Padi di Kecamatan Pendopo, Lintang Kanan, Pasemah Air Keruh, Ulu Musi, Talang Padang, dan Tebing Tinggi. Sedangkan sebaran overlay dengan data 3 paramater pemanfaatan lahan perkebunan dan pertanian termasuk dalam kategori hutan produksi biasa yang diman dapat dikategorikan pemanfaatan hutan tersebut aman.

Kata kunci: Tata Guna Lahan, SIG, Scoring, Overlay.

\section{PENDAHULUAN}

Sistem Informasi Geografis (SIG) yaitu suatu kesatuan sistem yang berbasis komputer untuk pengelolaan, penyimpanan, pemrosesan, analisis, dan penayangan data spasial dan non spasial yang terkait dengan permukaan bumi [1]. Oleh karena itu SIG mulai banyak digunakan dalam Pemerintahan Pusat maupun Daerah untuk mengetahui pendataan peta berbasis digital, salah satu penggunaan SIG ada pada penggunaan tata guna lahan.

Tata guna lahan menjadi sangat penting bagi pemerintah untuk mengetahui lahan yang digunakan oleh masyarakat yang dimana pemerintah pusat maupun daerah akan mengetahui potensi-potensi penghasilan yang 
paling banyak pada setiap daerah. Hasil yang didapat dengan adanya penggunaan SIG dalam studi geo-governance, dan menganalisis peta administrasi wilayah dan menggabungkan data dapat dijadikan solusi untuk situasi kritis lingkungan, sosial, dan ekonomi yang terlibat dalam pengelolaan penggunaan lahan pada setiap daerah [2].

Produksi sektor perkebunan yang paling mendominasi pendapatan disetiap Kecamatan yaitu Kopi, sedangkan untuk sektor pertanian yaitu Padi. Data yang didapat masih bersifat data statistik, dari hasil wawancara yang didapat bahwa penggunaan lahan masih didominasi penggunaan lahan pemerintah daerah oleh masyarakat, dan juga lahan yang disediakan oleh Perusahaan. Perubahan tata penggunaan lahan pertanian dan perkebunan dari tahun ke tahun selalu mengalami angka yang berbeda, Sistem Informasi Geografis dapat di manfaatkan untuk dominasi daerah dengan kesesuaian penggunaan lahan dengan menggunakan 4 parameter. Pemerintah Daerah juga dapat mengetahui sebaran daerah penggunaan lahan disetiap Kecamatan.

Adapun penelitian serupa dengan judul Sistem Informasi Geografis Tata Guna Lahan di Kabupaten Sleman, dimana tata guna lahan sangat penting sebagai pengembangan lahan yang berpotensi untuk suatu jenis tanaman agar tidak terjadi kerusakan pada tanaman dan lahan yang digunakan. Pemanfaatan SIG dengan tools Arcgis dapat dijadikan sebagai pengambilan keputusan dalam perencanaan dan pengelolaan, penggunaan lahan, dan sumber daya alam. Kabupaten Sleman mempunyai lahan perkebunan yang sangat luas dan subur serta memiliki iklim tropis basah, yang berpengaruh pada kesuburan tanaman. Teknik analisis data menggunakan Scoring dan overlay. Hasil yang didapat dengan menggunakan data spasial dan non spasial lahan perkebunan pada Kabupaten Sleman didominasi oleh lahan perkebunan Tembakau yang cocok di hampir setiap Kecamatan[2].

Teknik analisis data yang akan digunakan penulis yaitu scoring digunakan merepresentasikan tingkat kedekatan, keterkaitan, atau beratnya dampak tertentu pada suatu fenomena secara spasial dengan cara pemberian skor pada setiap parameter. Sedangkan overlay (tumpang susun peta) digunakan untuk menentukan kesesuaian lahan pertanian dan perkebunan di Kabupaten Empat Lawang dengan parameter yaitu peta jenis tanah, peta curah hujan, peta kemiringan lereng dan peta penggunaan lahan [3]. Parameter yang didapatkan menyesuaikan keadaan yang ada di Kabupaten Empat Lawang, dan mengikuti

Penelitian ini akan menghasilkan dominasi lahan perkebunan dan pertanian disetiap Kecamatan sekaligus hasil komoditas panen yang didapatkan data dari Dinas Pertanian dan Dinas Badan Pusat Statistik Empat Lawang.

\section{METODOLOGI PENELITIAN}

\subsection{Metode Scoring \& Overlay}

Scoring merupakan pemberian skor terhadap tiap kelas masing-masing parameter. Pemberian skor berdasarkan pada pengaruh kelas terhadap kejadian, semakin besar pengaruh 
terhadap kejadian maka semakin tinggi nilai skornya [4]. Pemberian nilai pada setiap parameter yaitu berkisar 1-5, sedangkan bobot nilai tergantung pada pengaruh dari setiap parameter yang memiliki faktor paling besar dalam pemetaan lahan pertanian dan perkebunan.

Model Scoring digunakan untuk merepresentasikan tingkat keterkaitan, kedekatan atau dampak tertentu terhadap suatu fenomena spasial. Setiap parameter akan diberikan skor dan dilakukan penjumlahan sehingga mendapatkan hasil sebuah tingkat keterikatan dan mendapatkan hasil akhir berupa klasifikasi tingkat keterikatan parameter keluaran [5]. Adapun gambaran tahapan analisis dalam metode scoring dapat dilihat pada gambar 1 .

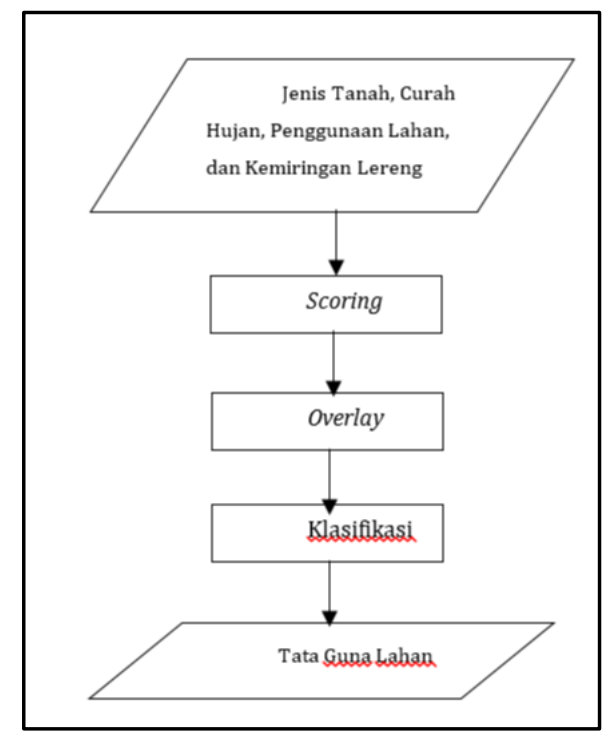

Gambar 1 Tahapan metode scoring

\section{a. Parameter Jenis Tanah}

Penggunaan parameter yang akan ada dalam penelitian untuk tata guna lahan pertanian dan perkebunan dalam memberikan skor sesuai dengan ketetapan dapat dilihat pada tabel 1 .

\section{Tabel 1 Skoring dan Kelas Parameter Jenis} Tanah

\begin{tabular}{|c|c|c|c|}
\hline $\begin{array}{l}\text { Kelas } \\
\text { Jenis } \\
\text { Tanah }\end{array}$ & Jenis Tanah & $\begin{array}{l}\text { Kepekaan } \\
\text { Tanah }\end{array}$ & Skor \\
\hline 1 & $\begin{array}{l}\text { Aluvial, Tanah, Glei, } \\
\text { Planossol, Hidromorf } \\
\text { Kelabu, Literite Air } \\
\text { Tanah }\end{array}$ & $\begin{array}{l}\text { Tidak } \\
\text { Peka }\end{array}$ & 15 \\
\hline 2 & Latosol & Agak Peka & 30 \\
\hline 3 & $\begin{array}{l}\text { Brown Forest Soil, } \\
\text { Non Calcic }\end{array}$ & $\begin{array}{l}\text { Kurang } \\
\text { Peka }\end{array}$ & 45 \\
\hline 4 & $\begin{array}{l}\text { Andosol, Laterictic } \\
\text { Gromusol, Podsolik }\end{array}$ & Peka & 60 \\
\hline 5 & $\begin{array}{l}\text { Regosol, Litosol } \\
\text { Organosol, Renzine }\end{array}$ & $\begin{array}{l}\text { Sangat } \\
\text { Peka }\end{array}$ & 75 \\
\hline
\end{tabular}

\section{b. Parameter Curah Hujan}

Penggunaan parameter curah hujan yang akan ada dalam penelitian untuk tata guna lahan pertanian dan perkebunan dalam memberikan skor sesuai dengan ketetapan dapat dilihat pada tabel 2.

\section{Tabel 2 Skoring dan Kelas Parameter Jenis} Tanah

\begin{tabular}{|c|c|c|c|}
\hline $\begin{array}{c}\text { Kelas } \\
\text { Jenis } \\
\text { Tanah }\end{array}$ & Jenis Tanah & $\begin{array}{c}\text { Kepekaan } \\
\text { Tanah }\end{array}$ & Skor \\
\hline 1 & $\begin{array}{l}\text { Aluvial, } \begin{array}{l}\text { Tanah, } \\
\text { Glei, }\end{array} \text { Planossol, } \\
\text { Hidromorf Kelabu, } \\
\text { Literite Air Tanah }\end{array}$ & $\begin{array}{l}\text { Tidak } \\
\text { Peka }\end{array}$ & 15 \\
\hline 2 & Latosol & $\begin{array}{l}\text { Agak } \\
\text { Peka }\end{array}$ & 30 \\
\hline 3 & $\begin{array}{l}\text { Brown Forest Soil, } \\
\text { Non Calcic }\end{array}$ & $\begin{array}{c}\text { Kurang } \\
\text { Peka }\end{array}$ & 45 \\
\hline 4 & $\begin{array}{l}\text { Andosol, Laterictic } \\
\text { Gromusol, Podsolik }\end{array}$ & Peka & 60 \\
\hline 5 & $\begin{array}{l}\text { Regosol, Litosol } \\
\text { Organosol, Renzine }\end{array}$ & $\begin{array}{l}\text { Sangat } \\
\text { Peka }\end{array}$ & 75 \\
\hline \multicolumn{4}{|c|}{ Sumber: berdasarkan SK Mentan No 837/kpts/Um/11/80[6] } \\
\hline \multicolumn{4}{|c|}{ Parameter Curah Hujan } \\
\hline
\end{tabular}


skor sesuai dengan ketetapan dapat dilihat pada tabel 3.

\section{Tabel 3 Skoring dan Kelas Parameter Curah Hujan}

\begin{tabular}{clcc}
\hline $\begin{array}{c}\text { Kelas } \\
\text { Curah }\end{array}$ & \multicolumn{1}{c}{ Deskripsi } & $\begin{array}{c}\text { Rata-rata } \\
\text { Curah Hujan } \\
\text { Hujan }\end{array}$ & Skor \\
\hline 1 & Sangat Rendah & $<5$ & 10 \\
2 & Rendah & $5-100$ & 20 \\
3 & Menengah & $101-300$ & 30 \\
4 & Tinggi & $301-500$ & 40 \\
5 & Sangat Tinggi & $>500$ & 50 \\
\hline Sumber: berdasarkan SK Mentan No 837/kpts/Um/11/80[6]
\end{tabular}

\section{d. Parameter Kemiringan Lereng}

Penggunaan parameter kemiringan lereng yang akan ada dalam penelitian untuk tata guna lahan pertanian dan perkebunan dalam memberikan skor sesuai dengan ketetapan dapat dilihat pada tabel 4 .

\section{Tabel 4.Klasifikasi Kelas Kemiringan Lereng}

\begin{tabular}{cllc}
\hline $\begin{array}{c}\text { Kelas } \\
\text { Kemiringan } \\
\text { Lereng }\end{array}$ & $\begin{array}{c}\text { Kemiringan } \\
(\%)\end{array}$ & \multicolumn{1}{c}{ Deskripsi } & $\begin{array}{c}\text { Sko } \\
\boldsymbol{r}\end{array}$ \\
\hline 1 & $0 \%-8 \%$ & Datar & 20 \\
2 & $8 \%-15 \%$ & Landai & 40 \\
3 & $15 \%-25 \%$ & Sedikit Curam & 60 \\
4 & $25 \%-45 \%$ & Curam & 80 \\
5 & $>45 \%$ & Sangat Curam & 100 \\
\hline Sumber: berdasarkan SK Mentan No 837/kpts/Um/11/80[6]
\end{tabular}

Overlay adalah kemampuan untuk menempatkan grafis satu peta diatas grafis peta yang lain dan menampilkan hasilnya pada plot. Overlay menampalkan suatu peta digital pada peta digital yang lain beserta atribut-atributnya dan menghasilkan peta gabungan pada keduanya sehingga menghasilkan informasi atribut dari kedua peta [7]. Secara singkatnya overlay disebut sebagai operasi visual yang membutuhkan lebih dari satu layer untuk digabungkan secara fisik. Overlay dapat dilakukan jika data telah diberikan skor.

\subsection{Metode Pengembangan}

Penelitian ini akan menggunakan metode waterfall. Metode ini biasa digunakan untuk proyek yang skalanya kecil. Adapun tahapantahapan dari metode ini adalah sebagai berikut:

\section{Perencanaan}

Tahapan ini adalah tahapan awal pada metode ini dimana masalah-masalah dan datadata yang berhubungan dengan sistem akan didefinisikan sehingga dapat diinventarisasi. Selain dari apa saja kebutuhan fisik yang dibutuhkan, dana dan tenaga kerja yang dibutuhkan juga termasuk dalam perencanaan sistem.

\section{Analisis}

Analisis sistem dapat diartikan sebagai proses untuk mengidentifikasi dan mengevaluasi permasalahan-permasalahan ataupun kebutuhan yang diharapkan sehingga usulan perbaikan bisa didapatkan.

\section{Perancangan}

Tahapan ini akan memproses data yang dibutuhkan untuk sistem yang baru yang merupakan hasil dari evaluasi permasalahan pada tahap sebelumnya.

\section{Evaluasi}

Evaluasi merupakan salah satu aspek yang diperlukan untuk menghasilkan bahwa rencana yang telah ditetapkan sama dengan pelaksanaan pengembangan sistem.

\section{Penerapan}

Tahap penerapan merupakan tahap terakhir dari metode pengembangan ini. Tahap 
ini akan menerapkan sistem agar siap untuk dioperasikan.

\section{HASIL DAN PEMBAHASAN}

\subsection{Hasil Jenis Tanah}

Dari hasil klasifikasi jenis tanah yang dilakukan didapatkan bahwa pengklasifikasian dengan pembobotan jenis tanah yang dapat dilihat pada tabel 5 .

Tabel 5. Pembobotan Klasifikasi Jenis Tanah

\begin{tabular}{clcc}
\hline $\begin{array}{c}\text { Kelas } \\
\text { Jenis } \\
\text { Tanah }\end{array}$ & Jenis Tanah & $\begin{array}{c}\text { Kepekaan } \\
\text { Tanah }\end{array}$ & Skor \\
\hline 1 & $\begin{array}{l}\text { Aluvial, Tanah, } \\
\text { Glei, Planossol, }\end{array}$ & Tidak Peka & 15 \\
& Hidromorf \\
& Kelabu, Literite \\
& Air Tanah & & \\
2 & Latosol & Agak Peka & 30 \\
3 & $\begin{array}{l}\text { Brown Forest } \\
\text { Soil, Non Calcic } \\
4\end{array}$ & Kurang Peka & 45 \\
& $\begin{array}{l}\text { Laterictic } \\
\text { Gromusol, }\end{array}$ & 60 \\
& $\begin{array}{l}\text { Podsolik } \\
\text { Regosol, Litosol } \\
5\end{array}$ & Sangat Peka & 75 \\
& $\begin{array}{l}\text { Organosol, } \\
\text { Renzine }\end{array}$ & \\
\hline
\end{tabular}

Dari referensi [6] berdasarkan SK Mentan No 837/kpts/Um/11/80 pembobotan / skoring yang dilakukan pada penelitian didapatkan suatu peta $\mathrm{j}$ enis tanah yang ada di Kabupaten Empat Lawang yaitu Aluvial, Latosol, dan Podsolik, berikut keadaan jenis tanah yang telah diberikan pembobotan dapat dilihat pada gambar 2 .

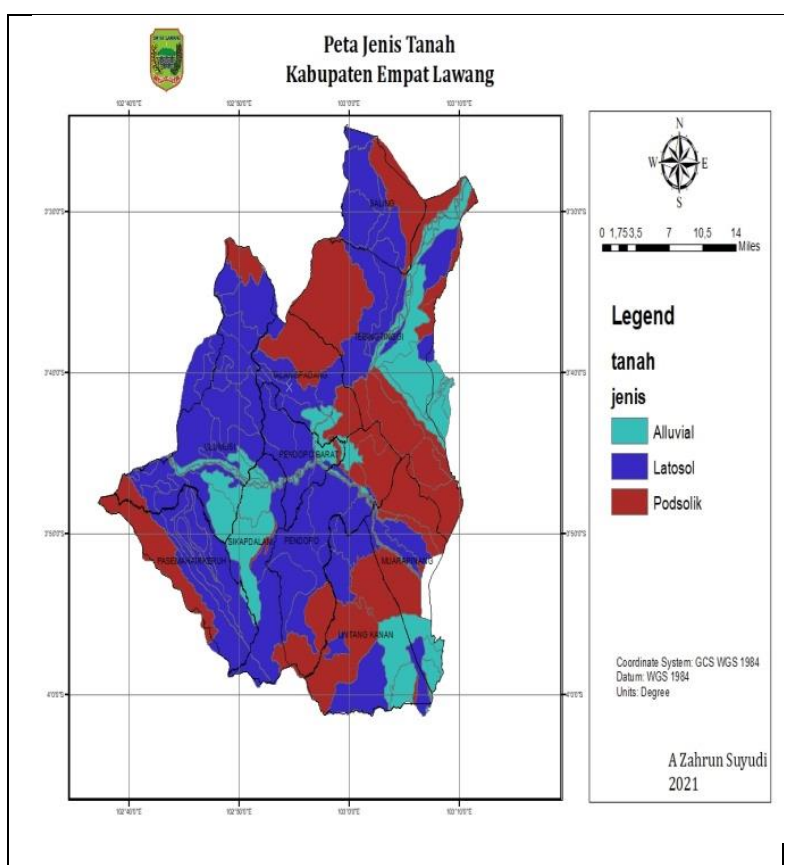

\section{Gambar 2. Peta Jenis Tanah Kabupaten Empat Lawang}

Jika dilihat dari gambar klasifikasi jenis tanah yang didapat bahwa jenis tanah podsolik dengan kepekaan kelas tanah 4 "peka" dengan skor 60, Dari hal tersebut didapatkan tanah podsolik bahwa warna dari tanah merah kuning yang cocok untuk sektor kelapa, karet, jambu mete, kelapa sawit dan tanaman-tanaman yang berjenis dengan penggemburan tanah tersebut[8]. Sedangkan dengan jenis tanah latosol dengan kelas tanah 2 "agak peka" dengan skor 30 dan cocok ditanami dengan tanaman padi, palawija, kakao, karet dan alluvial dengan kepekaan kelas tanah 1 "tidak peka" dengan skor 15 dan cocok digunakan pada tanaman-tanaman seperti padi, tebu, dan sayur-sayuran [9].

\subsection{Hasil Curah Hujan}

Pada hasil klasifikasi curah hujan, penulis mendapatkan data curah hujan pada tahun 2020 yang dapat dilihat pada tabel 6 . 
Tabel 6. Rata-rata Curah Hujan tahun 2020

\begin{tabular}{ll}
\hline \multicolumn{1}{c}{ Kecamatan } & Curah Hujan \\
\hline Lintang Kanan & $100-135$ \\
Muara Pinang & $105-142$ \\
Pasemah Air Keruh & $100-135$ \\
Pendopo & $103-140$ \\
Pendopo Barat & $111-151$ \\
Saling & $110-149$ \\
Sikap Dalam & $117-158$ \\
Talang Padang & $105-142$ \\
Tebing Tinggi & $104-141$ \\
Ulu Musi & $98-133$ \\
\hline
\end{tabular}

Berikut klasifikasi curah hujan yang digunakan dalam menghasilkan peta curah hujan yang berdasarkan SK Mentan No 837/kpts/Um/11/80. Dapat dilihat pada tabel 7.

Tabel 7. Klasifikasi Curah Hujan

\begin{tabular}{clcc}
\hline $\begin{array}{c}\text { Kelas } \\
\text { Curah } \\
\text { Hujan }\end{array}$ & Deskripsi & $\begin{array}{c}\text { Rata-rata } \\
\text { Curah } \\
\text { Hujan } \mathbf{~ m m}\end{array}$ & Skor \\
\hline 1 & Sangat & $<5$ & 10 \\
& Rendah & $5-100$ & 20 \\
2 & Rendah & $101-300$ & 30 \\
3 & Menengah & $301-500$ & 40 \\
4 & Tinggi & $>500$ & 50 \\
5 & Sangat Tinggi & \\
\hline
\end{tabular}

Dari pengklasifikasian yang dilakukan maka didapatkan peta curah hujan dengan ratarata curah hujan masuk dalam kelas menengah yaitu 101-300 dengan skor 30, peta dapat dilihat pada gambar 3.

Dari data curah hujan didapatkan bahwa kelas curah hujan hampir disetiap kecamatan yaitu berada pada menengah dengan rata-rata 101-300, sedangkan Kecamatan Ulu Musi dengan kelas curah hujan yang lebih rendah dengan rata-rata 5-100. Jika dilihat Kabupaten Empat Lawang merupakan salah satu Kabupaten dengan suhu menengah dan berada pada sifat hujan normal hingga dibawah normal.

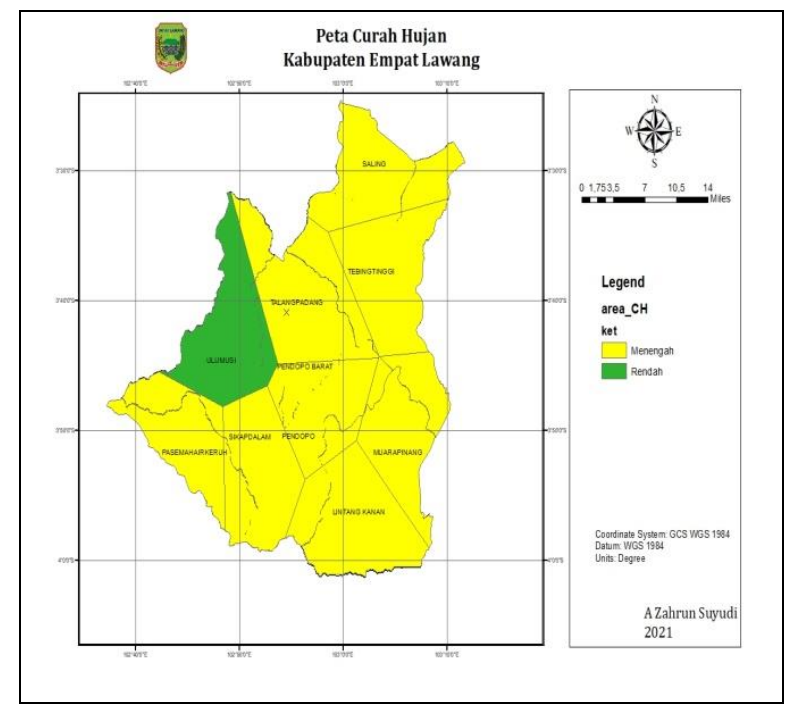

Gambar 3. Curah Hujan Kabupaten Empat Lawang

\subsection{Hasil Kemiringan Lereng}

Pada kelas kemiringan lereng didapatkan 5(lima) kelas yang teridentifikasi dengan mengacu pada relief lereng yang didapat. Berikut klasifikasi pada kemiringan lereng dapat dilihat pada tabel 8 .

Tabel 8. Klasifikasi Kelas Kemiringan Lereng

\begin{tabular}{cllc}
\hline $\begin{array}{c}\text { Kelas } \\
\text { Kemiringan } \\
\text { Lereng }\end{array}$ & $\begin{array}{c}\text { Kemiringan } \\
(\%)\end{array}$ & Deskripsi & Skor \\
\hline 1 & $0 \%-8 \%$ & Datar & 20 \\
2 & $8 \%-15 \%$ & Landai & 40 \\
3 & $15 \%-25 \%$ & Sedikit & 60 \\
& $25 \%-45 \%$ & Curam & 80 \\
4 & $>45 \%$ & Sangat Curam & 100 \\
\hline
\end{tabular}

Dari pembobotan yang didapat menghasilkan 5 kelas kemiringan yaitu curam, datar, landai, sedikit curam, dan sangat curam. Hasil dari pembobotan yang dilakukan dapat dilihat pada gambar 4. 


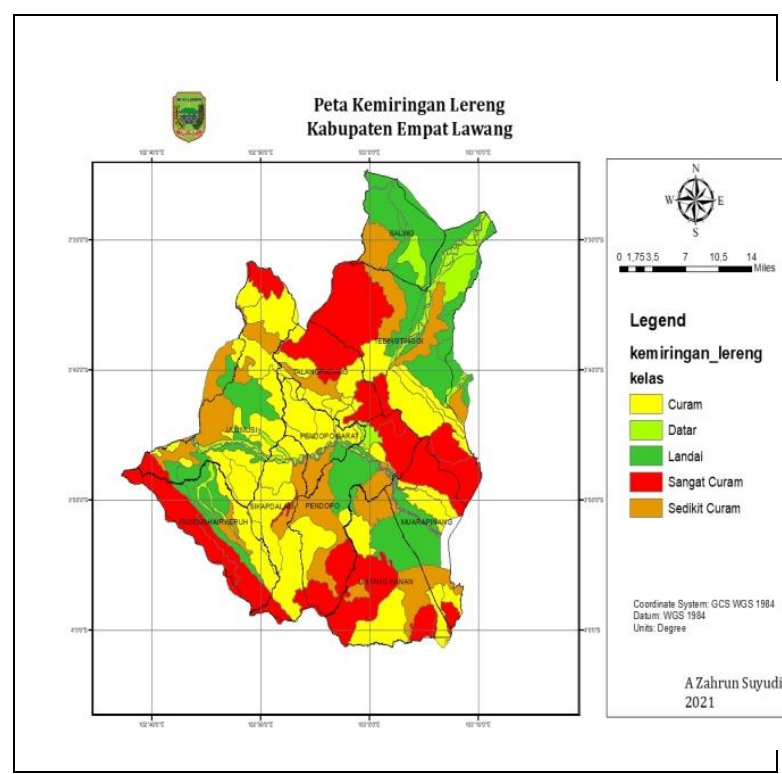

Gambar 4. Peta Kemiringan Lereng Kabupaten Empat Lawang

Jika dilihat dari hasil peta dapat disimpulkan bahwa kemiringan lereng kelas "curam" yang berada pada relief 25\%-45\% dengan skor 80, dilanjutkan dengan kelas "sangat curam" yang berada pada relief $>45 \%$ dengan skor 100, dan kelas "landai" berada pada relief 8\%-15\% dengan skor 40 . Ke 3 jenis kemiringan tersebut dapat digunakan dalam bercocok tanam dengan tanaman kacang komak, jagung, kacang tanah dan jenis pertanian dan perkebunan lainnya [10].

\subsection{Hasil Sebaran Overlay Perkebunan \& Pertanian}

Hasil persebaran Perkebunan dan Pertanian yang telah di overlay ditampilkan dimana penulis melihat sebaran paling mendominasi yaitu pada lahan perkebunan. Peta sebaran dapat dilihat pada gambar 5 .

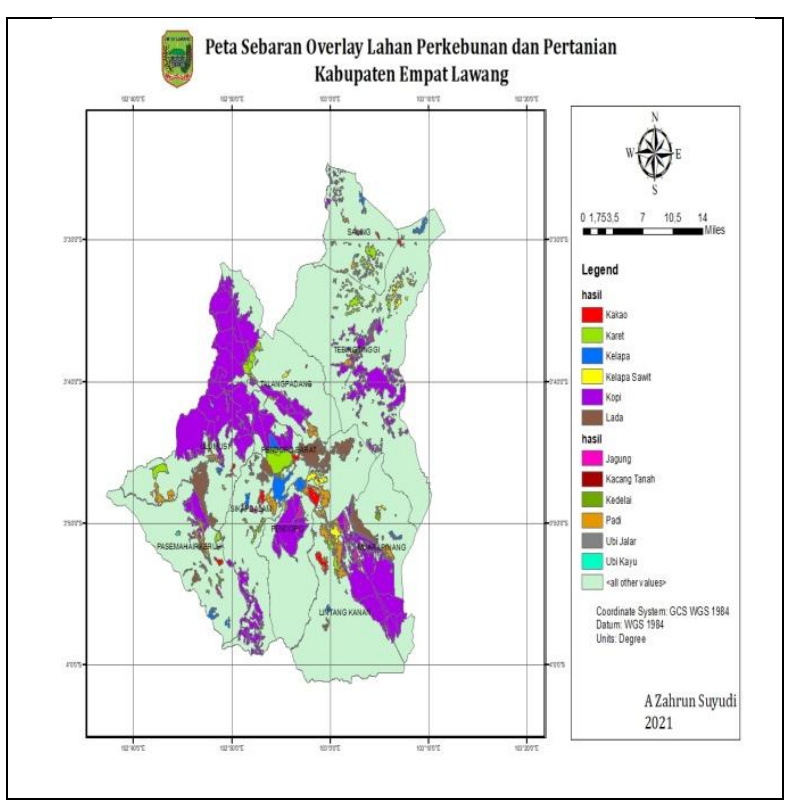

Gambar 5. Peta Sebaran Overlay Perkebunan \& Pertanian

Dari gambar 5. dapat dianalisis bahwa sebaran overlay lahan perkebunan lebih mendominasi dengan jenis perkebunan Kopi di Kecamatan Ulu Musi, Pendopo, Pendopo Barat, Lintang Kanan, Muara Pinang, Pasemah Air Keruh, dan Sikap Dalam data dilihat dari 4 peta parameter dan menyesuaikan data hasil akhir total keseluruhan hektar lahan perkebunan yang didapat dari data tersebut yaitu 1.949.677 hektar. Sedangkan untuk lahan pertanian lebih kecil dan didominasi oleh Padi di Kecamatan Pendopo, Lintang Kanan, Pasemah Air Keruh, Ulu Musi, Talang Padang, dan Tebing Tinggi untuk luas hektar yang didapatkan pada lahan pertanian yaitu 702.470 hektar. Luas hektar yang didapat diakumulasi dari data dari tahun 2015, 2016 dan 2017 jika dibandingkan dengan akumulasi total yang ada pada peta asli memiliki beberapa ketidak sinkronisasi baik dari data yang didapat dari Dinas Pertanian, dan web Badan Pusat Statistik hal ini dikarenakan adanya data duplikat, penulis telah mendapatkan data-data 
tersebut dari pengambilan data secara langsung dari objek sehingga analisis data yang terjadi diambil dari laporan akhir pemetaan komoditas pertanian dan perkebunan.

Penulis melakukan hasil sebaran overlay dengan melakukan akumulasi total parameter dari kelas curah hujan + jenis tanah + kemiringan lereng sehingga menghasilkan overlay pada lahan pertanian dan perkebunan sehingga menghasilkan peta sebaran yang dapat dilihat pada gambar 6.

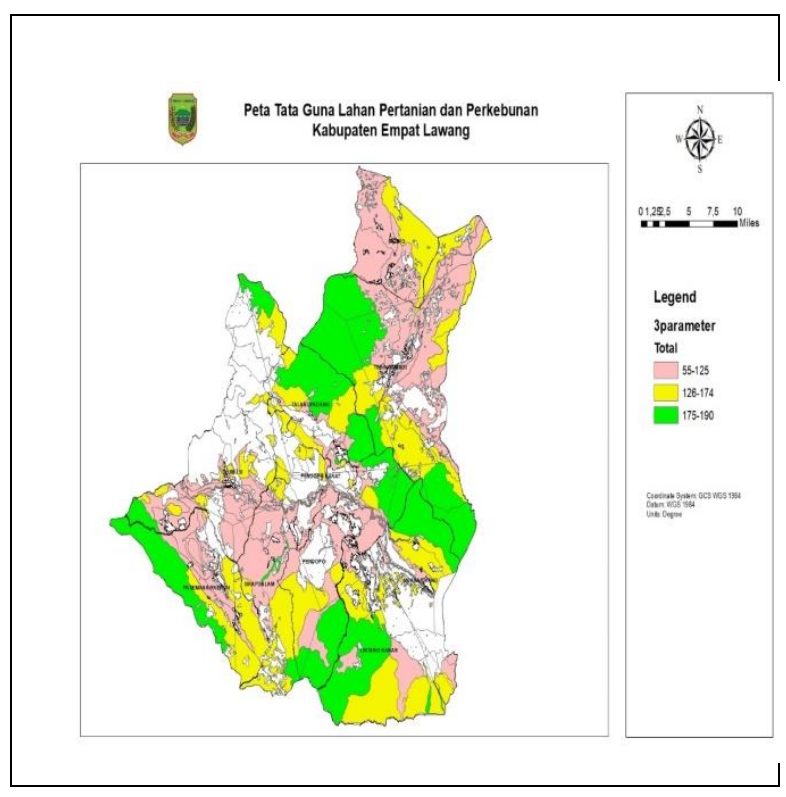

Gambar 6. Overlay Perkebunan dan Pertanian dengan 3 Jenis Parameter

Dari peta sebaran yang didapat bahwa mengacu pada SK Mentan yang dimana memiliki 3 kriteria pemanfaatan lahan dari hutan yaitu hutan lindung dengan skor $>175$, hutan produksi terbatas 125 - 174, dan hutan produksi biasa $<125$. Dari data diatas dapat dilihat bahwa penggunaan lahan perkebunan dan pertanian menggunakan pemanfaatan hutan produksi biasa dan hutan produksi terbatas. Pemanfaatan lahan yang digunakan mengacu pada 3 total parameter yang digunakan dari analisis dan hasil dari sumber-sumber yang penulis jadikan referensi bahwa lahan perkebunan dan pertanian yang dimanfaatkan masih dalam kategori aman dengan melihat kondisi curah hujan, jenis tanah, dan kemiringan lereng yang berada pada Kabupaten Empat Lawang. Kecamatan Ulu Musi memiliki cakupan lahan cukup besar pada lahan perkebunan dikarenakan hal tersebut dikategorikan sebagai pemanfaatan hutan produksi biasa.

\section{KESIMPULAN}

Berdasarkan hasil penelitian pemetaan tata guna lahan pertanian dan perkebunan Kabupaten Empat Lawang, penulis mengambil kesimpulan yaitu:

1. Hasil akhir dari sebaran overlay dari lahan pertanian dan perkebunan dianalisis bahwa sebaran overlay lahan perkebunan lebih mendominasi dengan jenis perkebunan Kopi di Kecamatan Ulu Musi, Pendopo, Pendopo Barat, Lintang Kanan, Muara Pinang, Pasemah Air Keruh, dan Sikap Dalam data dilihat dari 4 peta parameter dan menyesuaikan data hasil akhir. Sedangkan untuk lahan pertanian lebih kecil dan didominasi oleh Padi di Kecamatan Pendopo, Lintang Kanan, Pasemah Air Keruh, Ulu Musi, Talang Padang, dan Tebing Tinggi.

2. Dari sebaran overlay dengan data 3 paramater pemanfaatan lahan perkebunan dan pertanian termasuk dalam kategori hutan produksi biasa yang diman dapat dikategorikan pemanfaatan hutan tersebut aman. 


\section{DAFTAR PUSTAKA}

[1] M. W. Alkhalidi, B. Nadeak, and M. Sayuthi, "Sistem Informasi Geografis Pemetaan Wilayah Penyalahgunaan Narkoba Mengunakan Metode SOM (Self-Organizing Map) Studi Kasus: Kabupaten Aceh Tenggara," Build. Informatics, Technol. Sci., vol. 2, no. 1, pp. 1-9, 2020.

[2] D. M. D. U. Putra and P. Sugiartawan, "Sistem Informasi Geografis Tata Guna Lahan di Kabupaten Sleman," J. Sist. Inf. dan Komput. Terap. Indones., vol. 1, no. 3, pp. 175-184, 2019.

[3] I. Pratiwi and R. Ramli, "Pemetaan Kesesuaian Lahan Pertanian Dengan Menggunakan Sistem Informasi Geografis Di Kecamatan Kusambi Kabupaten Muna Barat," J. Penelit. Pendidik. Geogr., vol. 4, no. 3, pp. 3139, 2019.

[4] H. Hani'ah, A. Suprayogi, A. Sukmono, and others, "ANALISIS TINGKAT KERAWANAN BANJIR DI KABUPATEN SAMPANG MENGGUNAKAN METODE OVERLAY DENGAN SCORING BERBASIS SISTEM INFORMASI GEOGRAFIS," Universitas Diponegoro, 2018.

[5] D. M. Sihotang, "Metode Skoring dan Metode Fuzzy dalam Penentuan Zona Resiko Malaria di Pulau Flores," J. Nas. Tek. Elektro Dan Teknol. Inf., vol. 5, no. 4, pp. 302-308, 2016.

[6] Z. Zulkarnain, "Analisis Penetapan Kriteria Kawasan Hutan," Agrifor, vol. 12, no. 2, pp. 230-243, 2013.

[7] K. Darmawan, A. Suprayogi, and others, "Analisis tingkat kerawanan banjir di kabupaten sampang menggunakan metode overlay dengan scoring berbasis sistem informasi geografis," J. Geod. Undip, vol. 6, no. 1, pp. 31-40, 2017.

[8] B. P. d. P. Pertanian, "Tanah Podsolik," 2019.

https://www.litbang.pertanian.go.id/tahuk ah-anda/202/ (accessed Oct. 30, 2021).

[9] H. Hasriyanti, I. Abbas, and M. Nu. Z. Leo, "Aplikasi peta jenis tanah dalam mengidentifikasi lahan berpotensi untuk perkebunan kelapa sawit di Kecamatan Cendana Kabupaten Enrekang," $J$.
Pendidik. Geogr. Kajian, Teor. dan Prakt. dalam Bid. Pendidik. dan Ilmu Geogr., vol. 21, no. 1, pp. 12-21, 2016.

[10] J. Sudibyo and A. S. Kosasih, "Analisa Kesesuaian Lahan Hutan Rakyat di Desa Tambak Ukir, Kecamatan Kendit Kabupaten Situbondo," J. Penelit. hutan Tanam., vol. 8, no. 2, pp. 125-133, 2011. 